\title{
COVID-19 assistance needs to target energy insecurity
}

\begin{abstract}
The COVID-19 pandemic and associated changes in social and economic conditions may affect the prevalence of energy insecurity. Essential relief must be provided to the growing number of households that are energy insecure and protect them from even more dire circumstances caused by utility disconnections and unpaid energy bills.
\end{abstract}

\section{Michelle Graff and Sanya Carley}

E nergy insecurity - defined as the uncertainty that a household can pay its energy bills - is a persistent challenge faced by low-income households across the world ${ }^{1}$. In the US, as of 2015 , approximately 14 million households had unpaid utility bills, 17 million had received an energy disconnect notice, and 2 million were disconnected from the electric grid $^{2,3}$. When a household cannot pay its energy bills, residents may resort to unsafe financial behaviour, including payday lending, or heating behaviours, such as burning trash, using ovens and turning on space heaters ${ }^{4}$, which are a leading cause of home fires and responsible for $86 \%$ of deaths and $78 \%$ of injuries caused by domestic fires 5 . Additionally, approximately 25 million energy insecure households report making trade-offs between paying their utility bills and purchasing other necessities, such as nutritious food or healthcare services ${ }^{3,6}$. When households cannot afford to keep their homes at comfortable temperatures, they are more likely to suffer adverse mental and physical health impacts ${ }^{7}$, including disproportionately negative impacts on children ${ }^{8}$ and the elderly ${ }^{9}$ as well as higher frequencies of death ${ }^{10}$. Despite these alarming statistics, the US federal government has yet to formally recognize energy insecurity "as a distinct problem" 11 .

Prior to 2020, the rates of energy insecurity in the US were projected to rise. Reasons for these projections include rising electricity prices ${ }^{12}$ due to new energy infrastructure and policies ${ }^{13}-$ to which low-income households are more sensitive $^{14}$ - and the increasing incidence of extreme weather events, such as heat and cold spells due to climate change, which are more likely to affect energy insecure households because they tend to live in less energy-efficient homes ${ }^{15}$.

The COVID-19 pandemic now represents an unprecedented challenge for low-income populations, especially those that are already energy insecure. Those

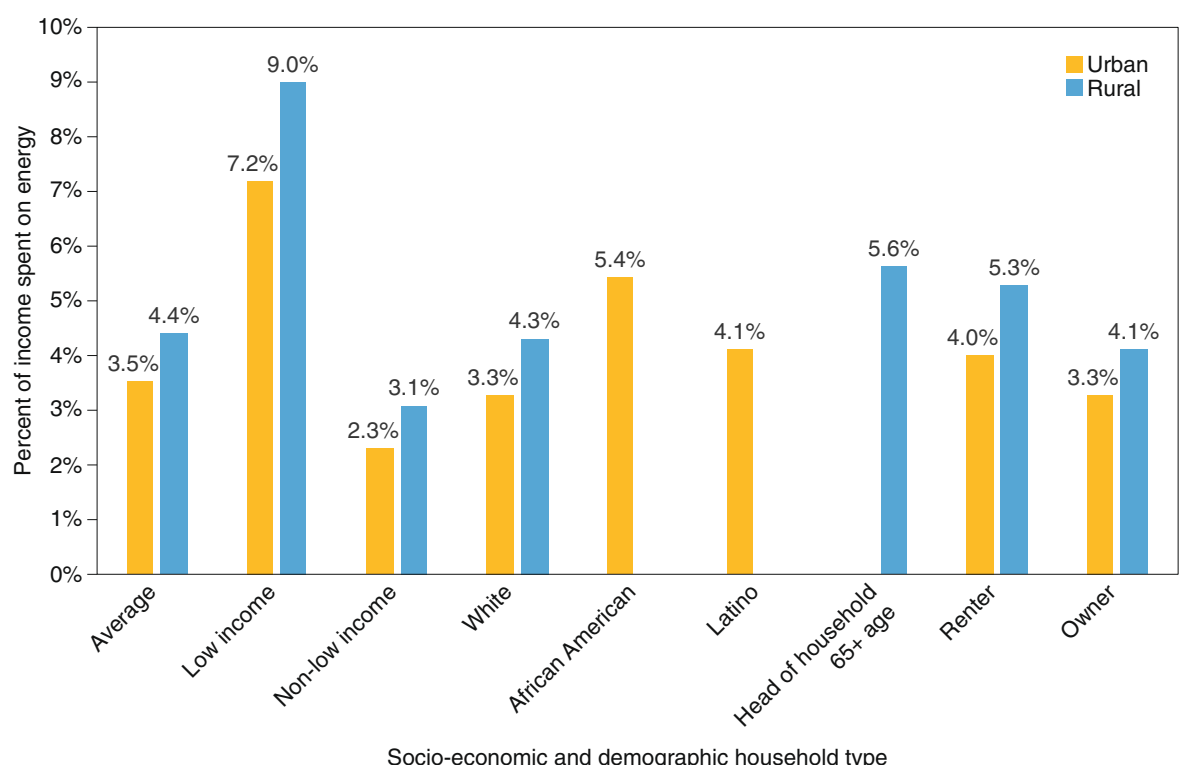

Fig. 1 | Percentage of income spent on energy. Percentage of income spent by urban and rural households on energy across different socio-economic and demographic groups. Data from refs. ${ }^{16,17}$.

that will be economically disadvantaged by COVID-19 are the same individuals that face potential or actual energy insecurity, and it is essential to provide rapid relief to these individuals. Relief options will vary by country and jurisdiction to reflect unique political and social contexts as well as existing policies. We offer several suggestions for relief specific to the US context, yet there are broader lessons that can be applied elsewhere as well.

\section{Energy insecurity and COVID-19}

The average urban (rural) household in the US spends $3.5 \%{ }^{16}(4.4 \%)^{17}$ of its income on energy (Fig. 1). However, certain socio-economic groups spend significantly more than this. Urban low-income and African American households, for example, spend 7.2 and $5.4 \%{ }^{16}$, respectively, and rural low-income residents pay $9 \%{ }^{17}$. Other demographic groups that tend to pay higher percentages, and therefore face more severe conditions of energy insecurity, include the elderly, non-white and renting populations ${ }^{17,18}$, as well as those that do not have a college education, do not work full time or are unmarried ${ }^{19}$.

Now, domestic unemployment has skyrocketed due to the COVID-19 pandemic as non-essential positions that cannot be fulfilled remotely are eliminated. In just the last two weeks of March 2020, as millions self-isolated across the country, individuals submitted nearly 10 million seasonally adjusted unemployment claims ${ }^{20}$. Many of the lost positions were in service and retail, production, food services, health care, construction and social assistance. Because much of this population lives paycheck to paycheck, a lack of income will make paying rent a financial hurdle, and stocking up on food or paying energy bills may be impossible. 
Economists predict that conditions will become more dire in the coming weeks and months. The Federal Reserve Bank of St. Louis, for example, predicts 47 million jobs may be lost in the second quarter of 2020 with a resulting $32 \%$ unemployment rate $^{21}$. Jobs that are most likely to be lost are non-salaried positions that cannot easily be performed off-site. Thus, not only is a significant portion of the population facing the possibility of losing all income, but the portion of the population that will be hardest hit is that which already receives lower salaries and has lower job security. Not only could low-income households' energy burdens worsen, a whole new population of households may be thrust into energy insecurity due to the pandemic.

\section{Energy is important in a pandemic}

In an effort to contain the virus, experts and politicians are encouraging, and in some cases mandating, that people stay at home. As a result of residential isolation - and the movement of personal and professional activities to the home - residential energy consumption will rise. So too will corresponding electricity bills.

Although the federal government has yet to recognize energy as a basic human right $^{18}$, the provision of electricity during the COVID-19 pandemic is necessary for all populations. As people are asked, or mandated, to stay at home, they will need energy for essential services, including temperature control, adequate lighting, refrigeration, cooking, powering medical devices and access to the internet to remain connected to friends, family and colleagues. These needs will likely rise in the coming months, especially as the summer heat requires more air conditioning. These various services are especially vital if a member of the household is sick with COVID-19 since medical treatment is now being provided by telehealth services; and access to comfortable temperatures, cooked and/or fresh food and powering of medical equipment will likely be necessary for recovery.

In addition, households with school- and college-aged children will need to power electronic devices to continue schooling at home so that they do not fall behind their academic curriculum. Employed adults also require electricity to work remotely and to maintain professional development, while those that are unemployed need electricity so they can pursue training opportunities and search for jobs.

\section{Recommended policy responses}

It is clear that COVID-19 will present health and economic challenges for low-income populations. Thus, policy responses are needed to help households afford energy use and avoid even more dire consequences, such as a loss of power, an inability to heat or cool one's home, or induced debt.

While the federal government's recent US $\$ 2$ trillion Coronavirus Aid, Relief, and Economic Security (CARES) Act is the largest emergency aid package in US history, it only provides US\$900 million in emergency contingency funding for the Low Income Home Energy Assistance Program (LIHEAP), the federal government's only program that focuses on helping low-income households pay their utility bills. By contrast, the stimulus package injected US $\$ 15$ billion into the country's food stamp program, the Supplemental Nutrition Assistance Program (SNAP). Although US $\$ 900$ million is a sizable contribution to LIHEAP, the program is historically underfunded, only assisting $22 \%$ of the income-eligible population each year ${ }^{22}$. Therefore, more funding will be required to help people pay their energy bills, especially as the percentage of households that live in energy insecurity increases.

Some states and utilities have made preliminary steps to protect their energy insecure populations. As of the end of March 2020, 22 states and Washington, DC, as well as several utilities, have ordered disconnection suspensions (that is, utilities are no longer allowed to disconnect customers if they cannot pay their bills); however, the actions vary widely. Some policies only narrowly apply to low-income residential customers and others include all customer classes. In addition, only some utilities are suspending late fee accruals; therefore, as the COVID-19 emergency abates, customers may face accumulated charges they will have to pay back.

Furthermore, only the state of Wisconsin has ordered that utilities are required to reconnect service to households that have been previously disconnected.

While these efforts are commendable, many other jurisdictions have yet to take action, and even the jurisdictions that have can go further. Here, we present several efforts that jurisdictions already have the authority to pursue to alleviate hardship during this formidable time, organized according to level of government. While these recommendations are specific to the US federalist system, governments across the world can pursue similar actions.

At the federal-level, upcoming stimulus packages should provide immediate and long-term relief to address energy insecurity. First, Congress should provide additional funding to LIHEAP — on top of the US\$900 million already allocated. This would allow households to keep up with their utility bills, and help customers avoid both disconnections and late fee accruals. Second, and simultaneously, Congress should expand LIHEAP's recipient eligibility from $150 \%$ of the federal poverty guidance to $200 \%$ for program year 2020-2021 so that the utility cash benefits can reach a larger population of households.

The federal government should also continue to provide aid to industries that, prior to the national emergency, demonstrated significant annual job increases but now must lay off or furlough workers due to the pandemic, including the energy efficiency and renewable energy sectors. Priority could be given to these industries to help them rebound more quickly and avoid collapse once the pandemic ends.

As the social distancing measures relax, Congress should provide substantial funding to the Weatherization Assistance Programs (WAP) to help low-income households increase their energy efficiency, reduce their utility bills, and ultimately reduce their energy burdens. Appropriating increased funding to WAP would both create efficiency-sector jobs and help households prepare for future economic or public health crises.

At the state-level, governors have the authority to require utilities to immediately suspend all gas and electric service disconnections; safely restore all previously disconnected utilities; and issue moratoria on all customer late fees, reconnection fees, rate hikes and other penalties. Governors should instruct all service providers, including investor-owned utilities, public utilities, municipal utilities and cooperative utilities, to execute these policies. To ensure that all providers comply with these regulations, governors should provide a backstop for smaller providers, such as rural co-ops, by guaranteeing any lost revenue from missed utility payments. As the pandemic eases and these disconnection and fee moratoria expire, state regulatory commissions should initiate energy affordability studies that aim to design policies, such as arrearage management programs and percentage-of-income payment plans, which will help low-income customers afford essential utility services.

At the local-level, municipal and county officials should work with their state-level energy assistance offices as well as their regional service providers to conduct large-scale outreach to eligible customers via e-mail and direct mailings - informing and encouraging them to apply for utility assistance. This would help these households make their monthly payments and thus avoid accruing late fees as the pandemic 
continues. Local governments should also generate and distribute educational materials to their constituents. Such communication may include online tutorials, training fliers and e-mails about how to reduce household energy bills, given the increase in home electricity consumption due to the stay-at-home precautions. They could also provide information with 'do it yourself' steps to weatherize your own home, such as replacing lightbulbs or caulking and weather-stripping your doors and windows.

These policies should be enacted quickly because the economic and health impacts of COVID-19 are already severe and growing by the day. When facing conditions of energy insecurity, a day without access to electricity might mean life or death for an individual in a household that requires power for medical equipment, an electronic device to speak to a doctor, heat or air conditioning to keep temperatures in a comfortable range, or refrigeration or a stove to keep food fresh and cooked safely.

While social distancing measures may help the US - as well as other countries - to 'flatten the curve', they present a formidable challenge to vulnerable groups who cannot afford to lose their jobs and quarantine at home. While the federal and state governments have taken some action to alleviate the inevitable growth of energy insecurity in the US, more is needed. A failure by federal, state, and local levels of government to recognize - and thereafter prioritize - energy security in their forthcoming legislative efforts to help US households navigate the COVID-19 pandemic will likely result in more negative health outcomes, as described above. For these reasons, we encourage all levels of government to promptly allocate resources to help Americans keep their lights on during the pandemic and without having to face irrecoverable debt as a result.

\section{Michelle Graff and Sanya Carley (D) $₫$}

Paul H. O'Neill School of Public and Environmental Affairs, Indiana University, Bloomington, IN, USA.

$凶_{\text {e-mail: scarley@indiana.edu }}$

Published online: 1 May 2020

https://doi.org/10.1038/s41560-020-0620-y

References

1. Brown, M. A., Soni, A., Lapsa, M. V. \& Southworth, K. Low-Income Energy Affordability: Conclusions from a Literature Review (Oak Ridge National Laboratory, 2019).

2. Seibens, J. Extended Measures of Well-Being: Living Conditions in the United States: 2011 70-136 (US Census Bureau, 2013).

3. 2015 Residential Energy Consumption Survey (US Energy Information Administration, 2018).

4. Hernández, D. J. Fam. Issues 37, 921-946 (2014).

5. Campbell, R. B. Home Fires Involving Heating Equipment (National Fire Protection Association, 2016).
6. Bhattacharya, J., DeLeire, T., Haider, S. \& Currie, J. Am. J. Public Health 93, 1149-1154 (2003)

7. Liddell, C. \& Morris, C. Energy Policy 38, 2987-2997 (2010).

8. Frank, D. A. et al. Pediatrics 118, el293-e1302 (2006).

9. Snyder, L. P. \& Baker, C. A. Affordable Home Energy and Health: Making the Connections (AARP, 2010); https://assets.aarp.org/ rgcenter/ppi/cons-prot/2010-05-energy.pdf

10. Berko, J. Natl Health Stat. Report 30, 1-15 (2014).

11. Bednar, D. J. \& Reames, T. G. Nat. Energy https://doi.org/10.1038/ s41560-020-0582-0 (2020).

12. Table 7.2a Electricity Net Generation: Total (All Sectors) (US Energy Information Administration, 2020); https://www.eia.gov/ totalenergy/data/monthly/pdf/sec7_5.pdf.

13. Fischer, C. Energy J. 31, 101-119 (2010).

14. Born, P. J. Econ. Lit. 46, 871-909 (2008).

15. Hernández, D. Am. J. Public Health 103, e32-e34. (2013).

16. Drehobl, A. \& Ross, L. Lifting the High Energy Burden in America's

Largest Cities: How Energy Efficiency Can Improve Low-Income and Underserved Communities (American Council for an Energy-Efficient Economy (ACEEE), 2016).

17. Ross, L., Drehobl, A. \& Stickles, B. The High Cost of Energy in Rural America: Household Energy Burdens and Opportunities for Energy Efficiency American Council for an Energy-Efficient Economy (ACEEE, 2018).

18. Hernández, D. Soc. Sci. Med. 167, 1-10 (2016).

19. Mohr, T. M. Energy Econ. 74, 360-369 (2018).

20. News Release (US Department of Labor, 2020); https://www.dol. gov/ui/data.pdf

21. Faria-e-Cstro, M. Back-of-the-envelope estimates of next quarter's unemployment rate. Federal Reserve Bank of St. Louis https://www.stlouisfed.org/on-the-economy/2020/march/ back-envelope-estimates-next-quarters-unemployment-rate (2020). 22. Welton, S. \& Eisen, J. Harv. Envtl. L. Rev. 43, 307-371 (2019).

\section{Acknowledgements}

We are grateful for the feedback on this Comment offered by G. Carlock and K. Hamman.

Competing interests

The authors declare no competing interests. 